\title{
ESTIMATION OF PHENOLIC CONTENT, FLAVONOID CONTENT, ANTIOXIDANT, AND ALPHA-AMYLASE INHIBITORY ACTIVITY OF SOME SELECTED PLANTS FROM SIRAHA DISTRICT NEPAL
}

\author{
NUMER ALAM, KHAGA RAJ SHARMA* \\ Central Department of Chemistry, Tribhuvan University, Kirtipur, Kathmandu, Nepal. Email: khagaraj_sharma33@yahoo.com
}

Received: 28 December 2019, Revised and Accepted: 25 January 2020

\section{ABSTRACT}

Objectives: The purpose of this research was to estimate the phenolic content, flavonoid content, antioxidant, antibacterial, and $\alpha$-amylase inhibitory activity of some selected plants such as Anethum sowa, Trigonella foenum-graecum, Lepidium sativum, Cuscuta reflexa, Eclipta alba, Leucas cephalotes, and Tinospora cordifolia collected from Siraha district of Nepal using in vitro studies.

Methods: Methanol extracts of these medicinal plants were prepared by cold percolation method. Preliminary phytochemical screening was performed by color differentiation method. Total phenolic and flavonoid content were estimated by Folin-Ciocalteu reagent method and aluminum chloride colorimetric method. Antioxidant potential was evaluated by 2,2-diphenyl-1-picrylhydrazyl radical scavenging assay. Furthermore, the $\alpha$-amylase enzyme inhibitory activity was studied using starch as a substrate, pancreatic $\alpha$-amylase as the enzyme, and acarbose as standard.

Results: Phytochemical screening showed that the plant extracts were found a rich source of secondary metabolites. The phenolic content estimation showed T. foenum-graecum $939.764 \pm 0.01$, L. sativum $551.63 \pm 0.02$, A. sowa $306.34 \pm 0.06$, L. cephalotes $233.19 \pm 0.03$, T. cordifolia $211.76 \pm 0.02$, E. alba $202.67 \pm 0.02$, and C. reflexa Roxb. $145.09 \pm 0.09 \mathrm{mg}$ milligram gallic acid equivalent per gram. The flavonoid content estimation showed T. cordifolia $852.07 \pm 0.11$, L. sativum $553.81 \pm 0.05$, E. alba $322.13 \pm 0.02$, A. sowa $329.02 \pm 0.05$, L. cephalotes $164.93 \pm 0.02$, and C. reflexa Roxb. $146.37 \pm 0.00 \mathrm{mg}$ milligram quercetin equivalent per gram. The antioxidant potential showed by $E$. alba $\mathrm{IC}_{50} 33.48 \pm 0.82 \mu \mathrm{g} / \mathrm{ml}$ and the values ranged from $E$. alba $33.48 \pm 0.82$ to $A$. sowa $47.62 \pm 1.09 \mu \mathrm{g} / \mathrm{ml}$. The $\alpha$-amylase inhibitory activity showed by A. sowa $76.78 \pm 2.00-E$. alba $777.36 \pm 9.66 \mu \mathrm{g} / \mathrm{ml}$. The result of brine shrimp toxicity showed $\mathrm{LC}_{50}$ value $>1000 \mu \mathrm{g} / \mathrm{ml}$. Among the seven plant extracts, only the plant extract of $E$. alba showed a zone of inhibition $14 \mathrm{~mm}$ against Staphylococcus aureus.

Conclusions: The plant extract of T. foenum-graecum showed the highest phenolic content, and T. cordifolia showed the highest flavonoid content. The highest antioxidant potential exhibited by $E$. alba and the highest $\alpha$-amylase inhibition activity showed by $A$. sowa. The plant extract of $E$. alba showed moderate antibacterial activity against $S$. aureus. All plant extracts were found non-toxic against brine shrimp larvae although further study is needed to assess its mechanism of action.

Keywords: Antioxidant, $\alpha$-Amylase, Gallic acid, Quercetin, Plant extract.

(c) 2020 The Authors. Published by Innovare Academic Sciences Pvt Ltd. This is an open access article under the CC BY license (http://creativecommons. org/licenses/by/4. 0/) DOI: http://dx.doi.org/10.22159/ajpcr.2020.v13i4.36734

\section{INTRODUCTION}

Nepal is rich in all the three levels of biodiversity, namely, species diversity, genetic diversity, and habitat diversity. In Nepal, the use of different parts of several medicinal plants to cure specific diseases has been in vogue since ancient times [1]. The use of herbal medicines in Asia represents a long history of human interaction with the environment. Plants used for traditional medicine contain a wide range of substances that can be used to treat chronic as well as infection diseases. Phytochemical from plants as safe and broadly effective alternatives with the less adverse effect is beneficial for biological activities such as anticancer, antimicrobial, antioxidant, analgesic, and wound healing $[2,3]$. Oxidation reaction can produce the free radicals, which starts chain reactions that damage the cells. Antioxidants are natural or synthetic substances that may prevent or delay oxidative cell damage [4]. Antioxidant plays the role on prevention of diabetes and other diseases too [5]. The antioxidant from natural sources neutralizes the radicals formed in the human body by oxidative stress. The plants secondary metabolites have pharmacological properties [6,7]. Today, numerous antimicrobial agents exist to treat a wide range of infections. The development of new anticancer and antimicrobial therapeutic agents from natural sources is one of the fundamental goals in medicinal chemistry [8].
Phenolic and flavonoid compounds are the main class of secondary metabolites in the plants and are divided into phenolic acids and polyphenols. The antioxidant activity of phenolic and flavonoid compounds is attributed to the capacity of scavenging free radicals, donating hydrogen atoms, electrons, or chelate metal cation [9]. Medicinal plants have been using since many years for the primary cure of different diseases in all most all countries of the world. Among the several diseases, diabetes is the seven leading causes of death. Hence, the search of potent natural compounds with high antioxidant potential is an urgent need. Due to the chronic hyperglycemic disturbances of carbohydrate, fat, and protein metabolism resulting from defect in insulin secretion, its action, and both causes diabetes mellitus [5]. The number of diabetes patients will be increased from 171 million from the year 2000 to 366 million or more by the year 2030 [5]. Mainly diabetes is of two types, Types 1 and II. Type 1 diabetes is due to insulin-deficient causes when pancreatic $\beta$-cell does not produce insulin, and Type II is insulin resistance. There are several factors of causing diabetes, although both genetic and environmental factors such as obesity, changing lifestyle eating habits, and lack of exercise play a significant role [5]. Long-term using oral hypoglycemic agents and insulin secretion agents lead to increase blood sugar level, drug resistance and affects the immune system of the body. To avoid such problems, the natural antidiabetic agents can be used for good management of diabetes [10]. The phytoconstituents reported to 
have antidiabetic activity, including carbohydrate hydrolyzing enzyme inhibition and antioxidant activity. $\alpha$-amylase secreted by the pancreas and salivary gland have a significant role in breaking down of starch and glycogen [5]. The $\alpha$-amylase is also found in microorganisms, plants, and higher organisms. $\alpha$-amylase catalyzes the hydrolysis of starch into a mixture of several oligosaccharides. Rapid breakdown of starch by $\alpha$-amylase may lead to increase blood sugar level, i.e., post-prandial hyperglycemia [5]. Inhibition of $\alpha$-amylase activity decreases the blood glucose level by delaying the carbohydrate hydrolysis and absorption in the blood.

The aim of the present study was to evaluate the antioxidant activity, estimation of phenolic and flavonoid content, antibacterial activity, $\alpha$-amylase inhibition activity, and toxicity of some plants collected from Siraha district of Nepal.

\section{METHODS}

\section{Collection and identification of plant materials}

The plant material was collected from Madar Village Development Committee of Siraha district Nepal. The plants were identified at the Central Department of Botany, Tribhuvan University, Kirtipur, Kathmandu. The list of plants with common name, family name, and parts used is shown in Table 1.

\section{Extract preparation}

The collected parts of plants were washed with tap water to remove the contaminants. The shade dried plant parts were grinded into powder form in an electric grinder and stored in a clean plastic bag at a low temperature until the used. The phytochemicals present in the powdered were extracted by cold percolation method using methanol as a solvent. Powdered plant parts (150 g) were kept separately in the clean and dry conical flasks. Methanol $(400 \mathrm{ml})$ was added to each flask and kept for each $72 \mathrm{~h}$ with frequent shaking. The mixtures were decanted and filtered with the help of cotton plug and thus obtained filtrates were concentrated with the help of rotatory evaporator. The concentrated filtrates were kept in a beaker wrapping with aluminum foil containing small pores to facilitate the evaporation of the solvent. These extracts were stored at $4{ }^{\circ} \mathrm{C}$ until performing the biological activities.

\section{Preliminary phytochemical analysis}

The preliminary phytochemical analysis was performed by color differentiation method adopting the protocol of Harbone with some modifications [11].

\section{2,2-Diphenyl-1-picrylhydrazyl (DPPH) radical scavenging assay}

The ability of different plant extracts to scavenge DPPH free radicals was estimated by the protocol given by Jamuna et al. [12]. The percentage of the DPPH free radical scavenging activity was calculated using the following equation,

$$
\text { Radical scavenging }(\%)=\left[\left(\mathrm{A}_{\mathrm{o}}-\mathrm{A}_{\mathrm{s}}\right) / \mathrm{A}_{\mathrm{o}}\right] \times 100
$$

where, $A_{0}=$ Absorbance of the control (DPPH solution+methanol), $A_{s}=$ Absorbance of test sample.

Table 1: List of some selected medicinal plants

\begin{tabular}{|c|c|c|c|}
\hline Plant sample & $\begin{array}{l}\text { Common } \\
\text { name }\end{array}$ & Family & Parts used \\
\hline Anethum sowa & Suwa & Umbelliferae & Leaf, stem \\
\hline $\begin{array}{l}\text { Trigonella } \\
\text { foenum-graecum }\end{array}$ & Methi saag & Fabaceae & Leaf \\
\hline Lepidium sativum & Chamsur saag & Brassicaceae & Leaf \\
\hline Cuscuta reflexa & Akash beli & Convolvulaceae & Whole part \\
\hline Eclipta alba & Bhringraj & Asteraceae & Stem, leaf \\
\hline Leucas cephalotes & Guma & Lamiaceae & $\begin{array}{l}\text { Stem, leaf, } \\
\text { flower }\end{array}$ \\
\hline $\begin{array}{l}\text { Tinospora } \\
\text { cordifolia }\end{array}$ & Gurjo & Menispermaceae & Stem, leaf \\
\hline
\end{tabular}

The $\mathrm{IC}_{50}$ value is indicated as the effective concentration of the sample that is required to scavenge $50 \%$ of the $\mathrm{DPPH}$ free radicals. $\mathrm{IC}_{50}$ values were calculated using the inhibition curve by plotting extract concentration versus the corresponding scavenging effect.

\section{Total phenolic content (TPC) estimation}

The total phenol content of all selected plant extracts was estimated using Folin-Ciocalteu reagent using gallic acid as standard based on oxidation-reduction reaction. The protocol adopted for the estimation of total phenol content was Kim et al. 2012 [13]. TPC content was expressed in milligram gallic acid equivalent per gram of dry weight (mg GAE/g) of extract using the formula, $\mathrm{C}=\mathrm{cV} / \mathrm{M}$ where, $\quad \mathrm{C}=$ total phenolic content, $\mathrm{c}=$ concentration of gallic acid established from the calibration curve in $\mathrm{mg} / \mathrm{ml}, \mathrm{V}=$ Volume of extract in $\mathrm{ml}, \mathrm{M}=$ Weight of plant extract.

\section{Total flavonoid content (TFC) estimation}

The TFC of the plant extracts was determined according to the aluminum chloride colorimetric method using quercetin as standard [14]. The stock solution of quercetin $(10,000 \mu \mathrm{g} / \mathrm{ml})$ was prepared by dissolving $10 \mathrm{mg}$ of quercetin in $1 \mathrm{ml}$ of methanol. Then, various concentrations of quercetin such as $10,25,50$, and $100 \mu \mathrm{g} / \mathrm{ml}$ were prepared by serial dilution of the stock solution. An aliquot of $0.5 \mathrm{ml}$ quercetin of each concentration in methanol was pipetted out into $20 \mathrm{ml}$ test tube containing $2 \mathrm{ml}$ of double-distilled water. Then, at the 0 time, $0.15 \mathrm{ml}$ of $5 \% \mathrm{NaNO}_{2}$ was added to the test tube. After $5 \mathrm{~min}, 0.15 \mathrm{ml}$ of $10 \%$ $\mathrm{AlCl}_{3}$ was added, and after $6 \mathrm{~min}, 1 \mathrm{ml}$ of $1 \mathrm{M} \mathrm{NaOH}$ were added to the mixture. Immediately, the total volume of the mixture was made up to $5 \mathrm{ml}$ by adding $1.2 \mathrm{ml}$ of distilled water and mixed thoroughly. Finally, the absorbance of the pink color mixture was measured at $510 \mathrm{~nm}$ using a spectrophotometer against blank solution containing all the reagents except quercetin. All the experiments were carried out in triplicate. The average absorbance values obtained at different concentrations of quercetin were used to plot the calibration curve.

The TFC in extract was expressed as milligrams quercetin equivalent per gram of dry weight (mg QE/g) which was calculated in all the extracts separately using the following equation:

$$
\mathrm{C}=\mathrm{cV} / \mathrm{m}
$$

Where, $\mathrm{C}=\mathrm{TFC} \mathrm{mg} \mathrm{QE} / \mathrm{g}$, $\mathrm{c}=$ Concentration of quercetin established from the calibration curve in $\mathrm{mg} / \mathrm{ml}, \mathrm{V}=$ Volume of extract in $\mathrm{ml}, \mathrm{m}=$ Weight of plant extract.

\section{Statistical analysis}

Data were recorded as a mean of three determinations of absorbance for each concentration, from which the linear correlation coefficient $\left(R^{2}\right)$ value was calculated. The regression equation is given as;

$$
\mathrm{Y}=\mathrm{mx}+\mathrm{c}
$$

where, Y=Absorbance, $\mathrm{m}=$ Slope from the calibration curve, $\mathrm{x}=$ Concentration of plant extracts and $\mathrm{c}=$ Intercept.

Using this regression equation concentration of extracts was calculated. Thus, with the calculated value of the concentration of each extract, the total phenolic content was calculated.

\section{$\alpha$-Amylase inhibitory activity}

The antidiabetic activity of plant extracts was calculated by $\alpha$-amylase inhibition assay proposed by Kusano et al. [15] with some modification. The undigested starch due to enzyme inhibition was detected through the blue starch iodine complex at $630 \mathrm{~nm}$ in spectrophotometer. The enzyme solution was prepared by dissolving $3 \mu \mathrm{g} / \mathrm{ml} \alpha$-amylase in $20 \mathrm{mM}$ phosphate buffer $\mathrm{pH}$ 6.9. $400 \mu \mathrm{l}$ of the substrate was pre-incubated with $200 \mu \mathrm{l}$ of varying concentrations $(640 \mu \mathrm{g} / \mathrm{ml}, 320 \mu \mathrm{g} / \mathrm{ml}, 160 \mu \mathrm{g} / \mathrm{ml}$, $80 \mu \mathrm{g} / \mathrm{ml}$, and $40 \mu \mathrm{g} / \mathrm{ml}$ ) of plant extracts and acarbose separately at $37^{\circ} \mathrm{C}$ for $5 \mathrm{~min}$. After this, $200 \mu \mathrm{l}$ of $\alpha$-amylase solution was added 
to each of them and then again incubated for $15 \mathrm{~min}$ at $37^{\circ} \mathrm{C}$. After incubation, the enzymatic reaction was quenched with $800 \mu \mathrm{l}$ of $\mathrm{HCl}$ $(0.1 \mathrm{M})$. Then, $1000 \mu \mathrm{l}$ of iodine reagent was added, and the absorbance was measured at $630 \mathrm{~nm}$. Then assay was carried out in triplicates. Percentage of enzyme inhibition was calculated using the following formula:

$\%$ Inhibition=1-[Abs2-Abs1/Abs4-Abs3] $\times 100$

where, Abs1=Absorbance of incubated mixture containing plant extract, starch, and amylase, Abs $2=$ Absorbance of incubated mixture containing plant extract and starch, Abs3=Absorbance of incubated mixture containing starch and $\alpha$-amylase, Abs $4=$ Absorbance of incubated solution containing starch only.

The standard graph was plotted by taking the concentration on the $\mathrm{X}$-axis and percentage inhibition on the Y-axis. With the help of this graph, $\mathrm{IC}_{50}$ value of each sample was calculated. The species having the lowest $\mathrm{IC}_{50}$ is considered to have the best $\alpha$-amylase inhibition property.

\section{Antibacterial activity}

Antibacterial activity of the plant extracts was performed by the agar well diffusion method. Effectiveness of antimicrobial substance was evaluated by determination of zone of inhibition (ZOI) by adopting the protocol Cavalieri et al. [16].

\section{Brine shrimp bioassay}

Brine shrimp, Artemia salina is a tiny crustacean. The eggs of brine shrimp are readily available at low cost, and they remain viable for years in the dry state. On being placed in a brine solution, the eggs hatch within $48 \mathrm{~h}$ providing large number of larvae. These larvae are used in this assay for toxicity test. This method is rapid, inexpensive, simple, and in-house approach for screening and monitoring physiologically active plant extracts. It determines the $\mathrm{LC}_{50}$ value $(\mathrm{S})(\mu \mathrm{g} / \mathrm{ml})$ for the crude extract (s). Compounds/extracts having $\mathrm{LC}_{50}$ values $<1000 \mathrm{ppm}(\mu \mathrm{g} / \mathrm{ml})$ are considered as pharmacological active. The assay was carried out by adopting the standard protocol of Meyer et al. [17]

\section{RESULTS AND DISCUSSION}

Quantitative estimation showed that the plant extracts are the rich sources of secondary metabolites with high yield percentage. The results of the yield percentage are shown in Table 2.

\section{Phytochemical screening}

The results of the phytochemical analysis are shown in Table 3. Most of the plant extracts are found as the rich source of secondary metabolites such as alkaloids, coumarins, flavonoids, glycosides, polyphenols, flavonoids, quinones, reducing sugars, and saponins.

\section{Antioxidant activity}

The antioxidant activity of each plant extract was measured using DPPH free radical. DPPH is scavenged by antioxidants through the donation of proton, forming the reduced DPPH. DPPH solutions show a strong absorbance band at $517 \mathrm{~nm}$, appearing as deep violet color. The color changes from purple to yellow after reduction, which can be quantified by its decrease of absorbance at wavelength $517 \mathrm{~nm}$.

The DPPH radical assay was performed for each plant extract using ascorbic acid as standard according to the standard procedure. In this assay, the mixture of DPPH with different concentrations of extract solution and ascorbic acid was separately incubated at room temperature, and absorbance was recorded at $517 \mathrm{~nm}$ by a spectrophotometer. The comparison of percentage radical scavenging between different plant extracts and ascorbic acid as standard is shown in Fig. 1.

The antioxidant potential of the plants extracts is influenced by the various factors and largely depends on both the composition of the extract and the analytical test system. The number of the plant constituents had been proven for the free radical scavenging or antioxidant activities, among the phenolic compounds are very important for the plant constituents. Total phenolic compounds of the plants and antioxidant activities have mutual relationships due to the presence of the hydroxyl group, which has the scavenging ability. By donating an electron, a phenolic compound can also scavenge the hydrogen peroxide and neutralize it to the water. The antioxidant potential of different plants was determined using DDPH assay and ascorbic acid as a standard compound ( $\mathrm{IC}_{50} 39.85 \pm 0.025 \mu \mathrm{g} / \mathrm{ml}$ ). Maximum antioxidant potential was found in Eclipta alba $\left(\mathrm{IC}_{50} 33.48 \pm 0.823\right)$ and minimum in Leucas cephalotes ( $\mathrm{IC}_{50} 52.86 \pm 1.80$ ). These results are shown in Table 4 . Similarly, results found that all the extracts exhibited maximum percentage of free radical scavenging activity at a dose of $100 \mu \mathrm{g} / \mathrm{ml}$ are shown in Table 5 from the literature review it is found that the antioxidant potential radical scavenging of Cuscuta reflexa has 76.38and $L$. cephalotes has $98.09 \pm 0.69[18,19]$.

\section{Antibacterial activity}

The ZOI showed by plant extracts on particular bacteria was measured for the estimation of their antimicrobial activity. The methanolic extract of Anethum sowa, Trigonella foenum-graecum, Lepidium sativum, C. reflexa, L. cephalotes, and Tinospora cordifolia did not show any ZOI at $100 \mathrm{mg} / \mathrm{ml}$. However, in the literature survey, it is found that the L. sativum shows the positive result [20]. The extract of E. alba was found to be resistant against Escherichia coli, whereas the same extract

Table 2: Percentage yield of different plant extracts

\begin{tabular}{llll}
\hline Plant sample & $\begin{array}{l}\text { Quantity of } \\
\text { sample (g) }\end{array}$ & $\begin{array}{l}\text { Quantity of } \\
\text { extract (g) }\end{array}$ & $\begin{array}{l}\text { Percentage } \\
\text { yield }\end{array}$ \\
\hline $\begin{array}{l}\text { Anethum sowa } \\
\text { Trigonella foenum- }\end{array}$ & 80 & 11 & 13.75 \\
graecum & 80 & 9 & 11.25 \\
Lepidium sativum & 80 & & \\
Cuscuta reflexa & 100 & 12 & 15 \\
$\begin{array}{l}\text { Eclipta alba } \\
\text { Leucas cephalotes }\end{array}$ & 100 & 12 & 12 \\
Tinospora cordifolia & 100 & 14 & 14 \\
\hline
\end{tabular}

Table 3: Phytochemical screening of methanol extract

\begin{tabular}{llllllll}
\hline Group of compounds & AB1 & AB2 & AB3 & AB4 & AB5 & AB6 & AB7 \\
\hline Alkaloid & + & + & + & + & + & - & + \\
Coumarins & + & + & + & + & + & + & + \\
Flavonoids & + & + & + & + & + & + & + \\
Glycosides & + & - & - & + & - & - & + \\
Polyphenols & - & + & - & + & + & + & + \\
Quinones & - & + & + & + & + & - & - \\
Reducing sugars & - & + & - & - & + & + & + \\
Saponins & + & - & + & + & - & - & + \\
Terpenoids & + & - & + & + & + & + & + \\
\hline
\end{tabular}

+: Presence and -: Absence, AB1: Anethum sowa, AB2: T. foenum-graecum, AB3: Lepidium sativum, AB4: Cuscuta reflexa, AB5: Eclipta alba, AB6: Leucas cephalotes, AB7: Tinospora cordifolia

Table 4: Comparison of IC ${ }_{50}$ values of different plant extracts with standard ascorbic acid

\begin{tabular}{ll}
\hline Plant sample/standard & $\mathbf{I C}_{\mathbf{5 0}}(\boldsymbol{\mu} \mathbf{g} / \mathbf{m l})$ \\
\hline Ascorbic acid & $39.85 \pm 0.025$ \\
Anethum sowa & $47.62 \pm 1.095$ \\
Trigonella foenum-graecum & $45.71 \pm 0.53$ \\
Lepidium sativum & $41.88 \pm 2.38$ \\
Cuscuta reflexa & $47.25 \pm 1.44$ \\
Eclipta alba & $33.48 \pm 0.823$ \\
Leucas cephalotes & $52.86 \pm 1.80$ \\
Tinospora cordifolia & $36.08 \pm 3.024$ \\
\hline
\end{tabular}




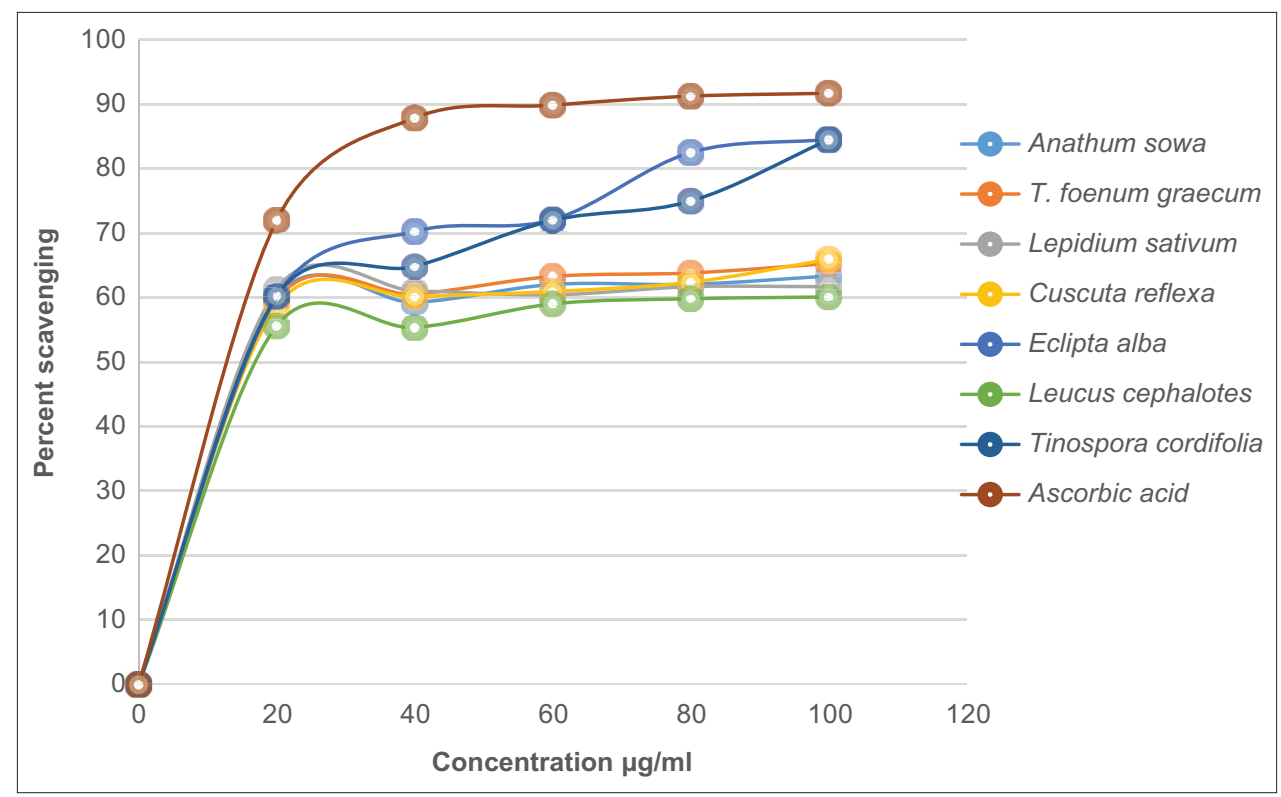

Fig. 1: Comparison of radical scavenging between ascorbic acid and plant extracts

Table 5: Percentage of radical scavenging with different concentration of plant extracts

\begin{tabular}{|c|c|c|c|c|c|c|c|c|}
\hline \multirow[t]{2}{*}{ Concentration $(\mu \mathrm{g} / \mathrm{ml})$} & \multicolumn{3}{|c|}{ Absorbance } & \multicolumn{3}{|c|}{ Percent scavenging } & \multirow[t]{2}{*}{ Mean } & \multirow[t]{2}{*}{ Mean \pm standard deviation } \\
\hline & Abs1 & Abs2 & Abs3 & S1 & $\mathbf{S 2}$ & S3 & & \\
\hline \multicolumn{9}{|l|}{ Anethum sowa } \\
\hline 40 & 1.073 & 1.065 & 1.059 & 58.9831 & 59.28899 & 59.5183 & 59.2635 & $59.26 \pm 0.26$ \\
\hline 60 & 1.01 & 1.015 & 0.953 & 61.39144 & 61.20031 & 63.5703 & 62.0540 & $62.05 \pm 1.31$ \\
\hline 80 & 1.007 & 0.965 & 1.004 & 61.50612 & 63.1162 & 61.6208 & 62.0795 & $62.07 \pm 0.89$ \\
\hline 100 & 1.012 & 0.898 & 0.966 & 61.31498 & 65.6727 & 63.07339 & 63.35372 & $63.35 \pm 2.19$ \\
\hline \multicolumn{9}{|c|}{ Trigonella foenum-graecum } \\
\hline 20 & 1.078 & 1.049 & 1.05 & 58.79205 & 59.9006 & 59.86239 & 59.5183 & $59.51 \pm 0.02$ \\
\hline 40 & 1.046 & 1.018 & 1.034 & 60.0152 & 61.0853 & 60.4740 & 60.5247 & $60.52 \pm 0.35$ \\
\hline 60 & 0.963 & 0.943 & 0.975 & 63.1880 & 63.952 & 62.7293 & 63.2900 & $63.29 \pm 0.7$ \\
\hline 80 & 0.932 & 0.92 & 0.986 & 64.3730 & 64.8318 & 62.3088 & 63.837 & $63.83 \pm 1.45$ \\
\hline 100 & 0.907 & 0.905 & 0.911 & 65.3287 & 65.4052 & 65.1785 & 65.30326 & $65.30 \pm 0.133$ \\
\hline \multicolumn{9}{|l|}{ Lepidium sativum } \\
\hline 20 & 1.012 & 0.996 & 1.032 & 61.3149 & 61.9266 & 60.5504 & 61.24 & $61.24 \pm 1.12$ \\
\hline 40 & 1.007 & 1.074 & 0.972 & 61.50612 & 58.94495 & 62.84404 & 61.04 & $61.04 \pm 3.18$ \\
\hline 80 & 1.049 & 0.93 & 1.026 & 59.90061 & 64.4495 & 60.77982 & 61.7 & $61.7 \pm 2.99$ \\
\hline 100 & 0.969 & 0.98 & 1.057 & 62.9587 & 62.5382 & 59.5948 & 61.69 & $61.69 \pm 2.4$ \\
\hline \multicolumn{9}{|l|}{ Cuscuta reflexa } \\
\hline 20 & 1.114 & 1.065 & 1.065 & 57.415 & 59.2889 & 59.2889 & 58.66 & $58.66 \pm 1.08$ \\
\hline 40 & 1.016 & 1.101 & 1.015 & 61.16208 & 57.9128 & 61.20031 & 60.09 & $60.09 \pm 1.88$ \\
\hline 60 & 1.006 & 1.038 & 1.02 & 61.54434 & 60.3211 & 61.0091 & 60.95 & $60.95 \pm 0.613$ \\
\hline 80 & 0.927 & 1.023 & 1.001 & 64.56422 & 60.894 & 61.7354 & 62.398 & $62.39 \pm 1.92$ \\
\hline 100 & 0.943 & 0.868 & 0.862 & 63.9526 & 66.8195 & 67.04893 & 65.9403 & $65.94 \pm 1.72$ \\
\hline \multicolumn{9}{|l|}{ Eclipta alba } \\
\hline 20 & 1.046 & 1.04 & 1.04 & 60.0152 & 60.2446 & 60.244 & 60.16 & $60.16 \pm 0.132$ \\
\hline 40 & 0.817 & 0.758 & 0.758 & 68.7691 & 71.0244 & 71.0244 & 70.27 & $70.27 \pm 1.3$ \\
\hline 60 & 0.708 & 0.741 & 0.741 & 72.935 & 71.6743 & 71.6743 & 72.09 & $72.09 \pm 0.72$ \\
\hline 80 & 0.485 & 0.443 & 0.443 & 81.46024 & 83.06575 & 83.06575 & 82.53 & $82.53 \pm 0.92$ \\
\hline 100 & 0.435 & 0.388 & 0.388 & 83.371 & 85.1682 & 85.168 & 84.56 & $84.56 \pm 1.032$ \\
\hline \multicolumn{9}{|l|}{ Leucas cephalotes } \\
\hline 20 & 1.145 & 1.156 & 1.156 & 56.23089 & 55.8104 & 60.244 & 55.59 & $55.59 \pm 0.24$ \\
\hline 40 & 1.146 & 1.053 & 1.146 & 56.19266 & 59.7477 & 71.0244 & 55.37 & $55.37 \pm 2.05$ \\
\hline 100 & 1.104 & 1.013 & 1.013 & 57.79817 & 61.2767 & 85.1678 & 60.11 & $60.11 \pm 2.008$ \\
\hline \multicolumn{9}{|l|}{ Tinospora cordifolia } \\
\hline 20 & 1.145 & 1.07 & 0.906 & 56.23089 & 59.0976 & 65.3669 & 60.23 & $60.23 \pm 4.67$ \\
\hline 40 & 0.859 & 1.053 & 0.848 & 67.1636 & 59.7477 & 67.5841 & 64.83 & $64.83 \pm 4.40$ \\
\hline 60 & 0.711 & 0.772 & 0.715 & 72.8211 & 70.489 & 72.6682 & 71.99 & $71.99 \pm 1.30$ \\
\hline 80 & 0.7 & 0.558 & 0.705 & 73.24159 & 78.669 & 73.0504 & 74.98 & $74.98 \pm 3.19$ \\
\hline 100 & 0.601 & 0.057 & 0.558 & 77.02599 & 97.821 & 78.6697 & 84.50 & $84.50 \pm 1.56$ \\
\hline
\end{tabular}


was not resistant against Staphylococcus aureus. Results obtained from the antibacterial screening of different extracts are tabulated in Table 6.

The extract of E. alba showed high growth inhibition against S. aureus, whereas the rest of the plant extract were found inactive against these microorganisms.

Table 6: Antimicrobial activity of plant extracts

\begin{tabular}{llll}
\hline $\begin{array}{l}\text { Plant sample } \\
\text { (extracts) }\end{array}$ & Bacteria & $\begin{array}{l}\text { ZOI (mm) of } \\
\text { extracts at } \\
\text { concentration } \\
\mathbf{1 0 0} \mathbf{~ m g / m l}\end{array}$ & $\begin{array}{l}\text { ZOI (mm) of } \\
\text { chloramphenicol } \\
\text { as control at } \\
\mathbf{1 0 0} \mathbf{~ m g / m l}\end{array}$ \\
\hline Anethum sowa & E. coli & - & 14 \\
Trigonella foenum- - & E. aureus & - & 18 \\
graecum & S. aureus & - & 14 \\
Lepidium sativum & E. coli & - & 18 \\
& S. aureus & - & 14 \\
Cuscuta reflexa & E. coli & - & 18 \\
& S. aureus & - & 14 \\
Eclipta alba & E. coli & - & 18 \\
Leucas cephalotes & S. aureus & 14 & 14 \\
& E. coli & - & 18 \\
Tinospora & S. aureus & - & 14 \\
cordifolia & E. coli & - & 18 \\
& S. aureus & - & 14 \\
\hline
\end{tabular}

$(-)=$ No effective antibacterial activity, ZOI: Zone of inhibition.

E. coli: Escherichia coli, S. aureus: Staphylococcus aureus

Table 7: Phenolic content in different plant extracts

\begin{tabular}{ll}
\hline Plant sample (extract) & TPC $\mathbf{~ m g ~ G A E} / \mathbf{g}$ \\
\hline Anethum sowa & $306.34 \pm 34$ \\
Trigonella foenum-graecum & $939.76 \pm 0.01$ \\
Lepidium sativum & $551.63 \pm 0.02$ \\
Cuscuta reflexa & $145.09 \pm 0.01$ \\
Eclipta alba & $202.67 \pm 0.02$ \\
Leucas cephalotes & $233.19 \pm 0.03$ \\
Tinospora cordifolia & $211.76 \pm 0.02$ \\
\hline
\end{tabular}

Total phenolic and flavonoid content

The result of phenolic content is displayed in Table 7. The total phenolic content of all plant extracts showed varied data ranging from 145.09 to $939.76 \mathrm{mg} \mathrm{GAE} / \mathrm{g}$ in C. reflexa Roxb. and T. foenum-graecum, respectively. The T. foenum-graecum has the highest total phenolic content, followed by $L$. cephalotes and T. cordifolia. The result showed similar results, as reported earlier $269.5 \pm 0.5 \mathrm{mg} \mathrm{GAE} / 100 \mathrm{~g}$ of total phenolic content in the E. alba [21].

The result of flavonoid content is shown in Table 8. Among the seven plants extract $T$. cordifolia showed the presence of the highest flavonoid contents, whereas the C. reflexa showed the least TFCs and other plants showed the flavonoids contents in between them. The results of the present study are found comparable to that of previously reported $142 \pm 0.15 \mathrm{mg} \mathrm{QE} / 100 \mathrm{~g}$ of total flavonoid in E. alba [22]. Antioxidant properties of flavonoids depend on their structure, particularly hydroxyl position in molecule although quantitative determination of flavonoid compounds in plant extracts is influenced by their structural complexity, diversity, nature of analytical assay method, selection of standard, and presence of interfering substances.

\section{In vitro $\alpha$-amylase inhibition activity}

The mode of $\alpha$-amylase inhibition of plant's extract was evaluated by determining the $\mathrm{IC}_{50}$ values, adopting the standard protocol given by Bernfeld [22]. Alpha-amylase inhibitory properties are presented in Fig. 2.

The result of IC $_{50}$ of $\alpha$-amylase inhibition activity of plant extract is shown in Table 9. The $\mathrm{IC}_{50}$ values of different plant extract along with standard acarbose were evaluated and found that the value range from $76.78 \mu \mathrm{g} / \mathrm{ml}$ to $777.36 \mu \mathrm{g} / \mathrm{ml}$. The extract of $A$. sowa having $\mathrm{IC}_{50}$ value $76.78 \pm 2.00 \mu \mathrm{g} / \mathrm{ml}$ was found to be potent toward the antidiabetic activity. The previous study reported that the aqueous leaves extracts of $P$. americana possess hypoglycemic activity [23]. Similarly, different fractions of $R$. ellipticus fruits were reported for its antidiabetic activity on alloxan-induced diabetes and glucose tolerance tests in rats [24]

\section{Toxicity test}

All the plant extracts showed $\mathrm{LC}_{50}>1000 \mu \mathrm{g} / \mathrm{ml}$ indicating the non-toxic effect. This method provides preliminary screening data that can be backed up by more specific bioassays once the active compounds have been isolated.

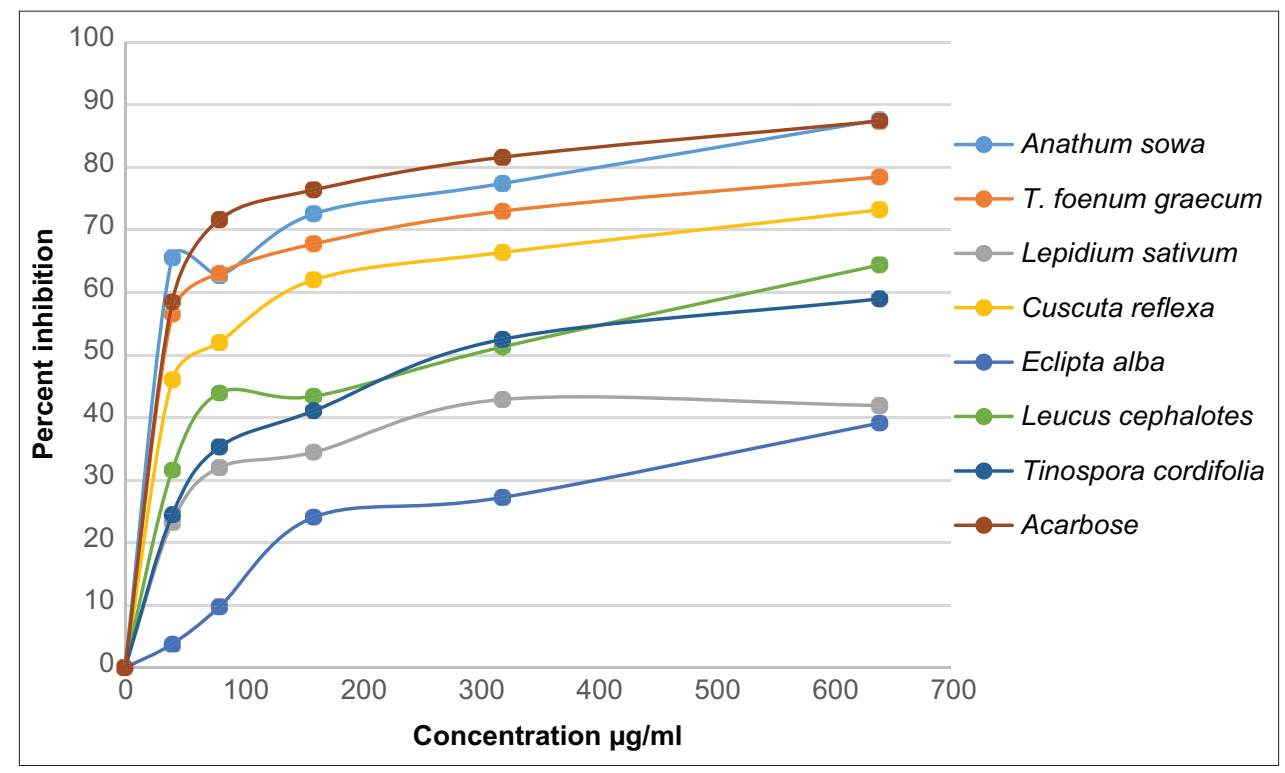

Fig. 2: Percent $\alpha$-amylase inhibition of plant extract in comparison to standard acarbose 
Table 8: Flavonoid content in different plant extracts

\begin{tabular}{ll}
\hline Plant sample (extract) & TFC $\mathbf{~ m g ~ Q E / g ~}$ \\
\hline Anethum sowa & $329.023 \pm 0.050$ \\
Trigonella foenum-graecum & $231.3817 \pm 0.0413$ \\
Lepidium sativum & $553.819 \pm 0.058$ \\
Cuscuta reflexa & $146.372 \pm 0.00936$ \\
Eclipta alba & $322.138 \pm 0.025$ \\
Leucas cephalotes & $164.9306 \pm 0.020$ \\
Tinospora cordifolia & $852.071 \pm 0.110$ \\
\hline
\end{tabular}

\section{CONCLUSIONS}

The present research provides some scientific support for their traditional use for diabetes management and other different diseases. From the phytochemical investigation, it can be concluded that plant extracts are the good sources of secondary metabolites. Radical scavenging activities of the methanolic extract of the selected plants showed a varied degree of antioxidant property, of which E. alba was found to have high antioxidant properties. The total phenolic contents were found high in T. foenum-graecum having value $939.76 \pm 0.01 \mathrm{mg}$ GAE/g, and least can be seen C. reflexa Roxb. (145.09 \pm 0.01$)$. Similarly, the TFCs of T. cordifolia were found to be highest having value of $852.07 \pm 0.011 \mathrm{mg} \mathrm{QE} / \mathrm{g}$ and least was found in C. reflexa (Roxb.) $146.372 \pm 0.096 \mathrm{mg} \mathrm{QE} / \mathrm{g}$, the greater antioxidant property on them is credited to secondary metabolites such as phenols and flavonoids. The most effective antidiabetic activity was found in the plant extract of $A$. sowa. The moderate and mild antidiabetic activity was shown respectively by the plant extracts of T. foenum-graecum and C. reflexa (Roxb.). The plant extract with lower $\mathrm{IC}_{50}$ value will be greatly beneficial to reduce the rate of digestion and absorption of carbohydrate and thereby contribute to effective treatment of diabetes by decreasing hyperglycemia.

\section{ACKNOWLEDGMENTS}

The authors are thankful to the Central Department of Chemistry, Tribhuvan University, for providing laboratory services to conduct this research work. We would like to thank Prof. Dr. Ram Prasad Chaudhary and Prof. Dr Mohan Siwakoti, Central Department of Botany, for the identification of collected plants.

\section{AUTHORS' CONTRIBUTIONS}

Dr. Khaga Raj Sharma analyzed the data and wrote the manuscript, whereas Numer Alam carried out the laboratory work. Both the authors read and approved the final manuscript.

\section{CONFLICTS OF INTEREST}

The authors declare that they have no conflicts of interest in publishing this research article.

\section{AUTHORS' FUNDING}

The authors themselves bear the publication fees of this paper.

\section{REFERENCES}

1. Joshi B, Lekhak S, Sharma A. Antibacterial property of different medicinal plants: Ocimum sanctum, Cinnamomum zeylanicum,
Xanthoxylum armatum and Origanum majorana. Kath Univ J Sci 2009;5:143-50.

2. Subedi A, Amatya MP, Shrestha TM, Mishra SK, Pokharel BM. Antioxidant and antibacterial activity of methanolic extract of Machilus odoratissima. Kath Uni J Sci Eng Tech 2012;8:73-80.

3. Gokhale $M$, Wadhawani M. Antimicrobial activity of secondary metabolites from plants-a review. Int J Pharmacognosy 2015;2:60-5.

4. Sridevi P, Budde S, Neeraja T, Raju BM, Adapa B. Antioxidants and their role in disease management. Int J Med Res Health and Sci 2018;7:175-90.

5. Kamtekar S, Keer V, Patil V. Estimation of phenolic content, flavonoid content, antioxidant and alpha amylase inhibitory activity of marketed polyherbal formulation. J Appl Pharm Sci 2014;4:61-5.

6. Sudha P, Zinjarde SS, Bhargava SY, Kumar AR. Potent $\alpha$-amylase inhibitory activity of Indian ayurvedic medicinal plants. BMC Complement Altern Med 2011;11:5.

7. Paul T, Banerjee S. In vitro evaluation of $\alpha$-amylase inhibitory activity and antioxidant potential of Pteris vittata $\mathrm{L}$. with special reference to its HPTLC profile. Int J Pharm Bio Sci 2013;4:494-503.

8. Ganesan A. The impact of natural products upon modern drug discovery. Curr Opin Chem Biol 2008;12:306-17.

9. Kasote DM, Katyare SS, Hegde MV, Bae H. Significance of antioxidant potential of plants and its relevance to therapeutic applications. Int $\mathrm{J}$ Biol Sci 2015;11:982-91.

10. Mishra LC. Scientific Basis for Ayurvedic Therapies. $1^{\text {st }}$ ed. Boca Raton, USA: CRC Press; 2003. p. 102.

11. Harbone JB. Phytochemical Methods: A Guide to Modern Techniques of Plant Analysis. London, New York: Champman and Hall Ltd.; 1973. p. 279.

12. Jamuna S, Paulsamy S, Karthika K. Screening of in vitro antioxidant activity of methanolic leaf and root extract of Hypochaeris radicata $\mathrm{L}$ (Asteraceae). J Appl Pharm Sci 2012;2:149-154.

13. Khan MS, Yusufzai SK, Rafatullah M, Sarjadi MS, Razlan M. Determination of total phenolic content, total flavonoid content and antioxidant activity of various organic crude extracts of Licuala Spinosa Leaves from Sabah, Malaysia. ASM Sci J 2018;11:53-8.

14. Pallab K, Tapan B, Tapas P, Ramen K. Estimation of total flavonoid content (TFC) and antioxidant activities of methanolic whole plant extract of Biophytum sensitivum Linn. J Drug Deliv Ther 2013;3:33-7.

15. Kusano R, Ogawa S, Matsuo Y, Tanaka T, Yazaki Y, Kouno I. $\alpha$-Amylase and lipase inhibitory activity and structural characterization of acacia bark proanthocyanidins. J Nat Prod 2011;74:119-28.

16. Cavalieri SJ, Rankin ID, Harbeck RJ, Sautter RL. Manual of antimicrobial susceptibility testing. Am Soc Microbial 2015;???:???

17. Meyer BN, Ferrigni NR, Putnam JE, Jacobsen LB, Nichols DE, McLaughlin JL. Brine shrimp: A convenient general bioassay for active plant constituents. Planta Med 1982;45:31-4.

18. Sandeep, Mittal A. Evaluation of antimicrobial and antioxidant activity of isolated constituents from areal part of cuscuta reflexa Roxb plant. Asian J Pharm Clin Res 2018;3:187-90.

19. Sharma S, Hullatti KK, Kumar S, Brijesh TK. Comparative antioxidant activity of Cuscuta reflexa and Cassytha filiformis. J Pharm Res 2012;5:441-3.

20. Dogruoz N, Zeybek Z, Karagoz A. Antibacterial activity of some plant extracts. IUFS J Biol Res 2008;67:17-21.

21. Yadav NK, Arya RK, Dev K, Sharma C, Hossain Z, Meena S, et al. Alcoholic extract of Eclipta alba shows in vitro antioxidant and anticancer activity without exhibiting toxicological effects. Oxid Med Cell Longev 2017;2017:9094641.

22. Bernfeld P. Amylases alpha and beta. In: Methods in Enzymology. Vol. 1. New York: Academic Press; 1955. p. 149-58.

23. Antia BS, Okokon JE, Okon PA. Hypoglycemic activity of aqueous leaf extract of Persea americana Mill. Indian J Pharmacol 2005;37:325-6.

24. Sharma US, Kumar A. Anti-diabetic effect of Rubus ellipticus fruit extracts in alloxan-induced diabetic rats. J Diabetol 2011;2:1-6. 